\title{
AN EXAMPLE OF COMPLIANCE VERIFICATION OF PAVEMENT PROJECT SPECIFICATIONS BY MEANS OF GEOPHYSICS
}

\author{
Carolina Narjara Mazzini Amaral ${ }^{1}$ and Lúcia Maria da Costa e Silva²
}

\begin{abstract}
The most important information about asphalt pavement is layer thickness. This information indicates whether or not the project specifications were met, and can also direct future recovery plans. Verifying these data usually relies on destructive techniques, such as boreholes, which may be expensive or even render verification unfeasible. Using the electromagnetic geophysical method known as ground penetrating radar (GPR), it is possible to verify compliance with pavement project specifications in an efficient and non-destructive way. We present an example of the use of GPR for this purpose obtained on a paved road at the campus of the Universidade Federal do Pará (UFPA), in Brazil. The GPR survey enabled individual pavement layers be identified. The comparison of the thickness of these layers, and those found in a borehole drilled during the GPR survey, with the thickness specified by the construction project plans, showed significant discrepancies.
\end{abstract}

Keywords: ground penetrating radar, GPR, asphalt layer thickness.

RESUMO. As informações mais importantes sobre o pavimento astáltico são a espessura de suas camadas. Estas quantidades indicam se as especificações do projeto foram atendidas e podem também direcionar planos futuros de recuperação. A verificação desses dados depende geralmente de técnicas destrutivas, tais como perfurações, que podem encarecê-la ou até torná-la inviável. Com o método geofísico GPR é possível verificar o cumprimento das especificações de projeto de pavimentação asfáltica de maneira eficiente e não destrutiva. Apresentamos um exemplo obtido em uma estrada pavimentada no campus da Universidade Federal do Pará (UFPA, Brasil) que permitiu a identificação das camadas do pavimento com o GPR. A comparação dessas espessuras e daquelas obtidas por meio de um furo perfurado durante o levantamento GPR com as espessuras especificadas pelo projeto de construção mostram discrepâncias significativas.

Palauras-chave: radar de penetração do solo, GPR, espessura de pavimentação astáltica.

\footnotetext{
${ }_{1}^{1}$ Fgeoteam (R. Domingos Marreiros, 394/s.11, Umarizal, 66055-210 Belém, PA, Brazil) and Universidade Federal do Pará, Centro de Geociências, Curso de PósGraduação em Geofísica (UFPA/CG/CPGF) (R. Augusto Corrêa, 1, Guamá, 66075-110 Belém, PA, Brasil), PA, Brazil. Phone: +55(91) $98391-9674$

- E-mail:carol_narjara@yahoo.com.br

${ }^{2}$ Serviço Geológico Brasileiro/CPRM-SUREG/PA (Av. Dr. Freitas, 3645, Marco, 66095-110 Belém, PA, Brazil) and UFPA/CG/CPGF (R. Augusto Corrêa, 1, Guamá, 66075-110 Belém, PA, Brazil). Phone: +55(91) 3182-1335 - E-mail: lucia.costaesilva@cprm.gov.br
} 


\section{INTRODUCTION}

It is important to keep paved streets well maintained not only for aesthetics but also to ensure traffic safety.

The pavement that makes up roads is composed of a series of layers on top of either a leveled surface or natural terrain. All pavements have a certain lifetime or service life, i.e., a time after which their useful characteristics become compromised or obsolete.

The most important information about asphalt pavement is layer thickness. This information indicates if the parameters specified in the project were followed (quality control), and can guide potential recovery plans in the case that they were not. This information traditionally relies on samples obtained from boreholes, a technique that destroys the pavement, is time-consuming, can be expensive or even impossible to conduct, and is discontinuous.

Ground penetrating radar (GPR) is a geophysical method which uses electromagnetic waves to investigate the subsurface. This method is used in archaeological, environmental, geotechnical, and groundwater investigations, as well as in mineral prospecting, civil engineering, and myriad other fields (Daniels, 2004; Jol, 2009).

The first study of applying GPR to pavements was performed in the United States in the 1970s by the Federal Highway Administration (FHWA), to test the applicability of GPR for evaluating the pavement conditions of tunnels and bridges, according to Morey (1998). About twenty years later, GPR began to see widespread use in pavement studies. Works such as those by Hugenschmidt et al. (1998), Hickman et al. (2000), Lenngren et al. (2000), Maser (2002), Angió et al. (2003), and Lahouar \& Al-Qadi (2008), show examples of the use of GPR in the inspection of pavements. The primary goals in this application are to map defects (fissures, fractures, and cracks), define layers, and identify moisture zones.

Nowadays, GPR is used in many countries to study asphalt pavement thicknesses and defects quickly, inexpensively, noninvasively, and non-destructively, and in some countries vehiclemounted GPRs are being employed (for example Dong et al., 2016). However, this use is still uncommon in Brazil.

The first academic works with GPR for pavements in Brazil were probably conducted by Aguiar (2005) and Lopes (2009). The former tested the applicability of GPR to the detection of the pavement - substrate interface, and identification of the pavement's proximity to the water table, by integrating geodetic data with GPR data obtained on a stretch of the Alça Viária Highway in the state of Pará.

Using the GPR data, it was possible to correlate defects visible on the surface with features in radargrams, identify the groundwater level, and classify the substrate as clayey soil. It is this soil, capable of blinding the GPR signal, and common to many Brazilian regions, along with the tropical weather and abundant rainfall, that explains in part the infrequent use of GPR in Brazil. The GPR study by Lopes (2009) was conducted on sections of pavement on the campus of the Federal University of Rio de Janeiro (Universidade Federal do Rio de Janeiro, UFRJ). The GPR data were correlated with deflectometry data. The results made it possible to locate piping under the pavement, to distinguish various layers within the pavement, and to evaluate the compaction of the subgrade.

Airport pavements were also studied (Lima-Filho et al., 2004; Gomes, 2008; Borges et al., 2014), but these have different characteristics than the type of pavement studied in the present work.

Following a trend which sees universities introducing GPR in Brazil, field tests in pavement have been performed at the Universidade Federal do Pará (UFPA) at the Guamá Sector III campus, near the Center of Excellence in Energy Efficiency of the Amazon (CEAMAZON). In several areas of the city of Belém, the pavement deteriorates very easily. This is believed to be due to the rainy weather, but other hypotheses are: contracting deficient paving, and non-compliance with the original pavement project specifications. The present study was motivated by a desire to evaluate the latter hypothesis. In addition, since the conductivity of the terrain is generally considered to be quite high, the work also aimed to test the utility of a high frequency antenna $(900 \mathrm{MHz})$ in this type of environment, which had not yet been carried out.

\section{PAVEMENT STRUCTURE}

Pavements can be classified into three types, according to their composition: hard, semi-hard, and flexible or asphaltic (Bernucci et al., 2006; Alves, 2007). The hard and semi-hard pavements are characterized by the presence of one or more layers of concrete in their structures. Flexible pavements, also known as asphaltic, are the most common used for paving because asphalt is waterproof, resistant, and durable.

Asphalt pavement usually has four layers: i) a coating of asphalt mixed with gravel or pebble, ii) a base with bitumen and gravel or pebble, iii) a sub-base of gravel or pebble and iv) a subgrade reinforcement.

According to the specifications of the road construction contract studied by this work, it would be formed by four layers, described below, from top to bottom (Fig. 1). The first layer, $5 \mathrm{~cm}$ thick, corresponds to the asphalt cover. The second layer, called the base, would be $20 \mathrm{~cm}$ thick, and composed of gravel and 
sand with bitumen sealant. The third, the sub-base, would also be $20 \mathrm{~cm}$ thick, and would be composed of gravel and sand. Finally, the fourth and last layer, subgrade reinforcement, also $5 \mathrm{~cm}$ thick, would be formed of gravel.

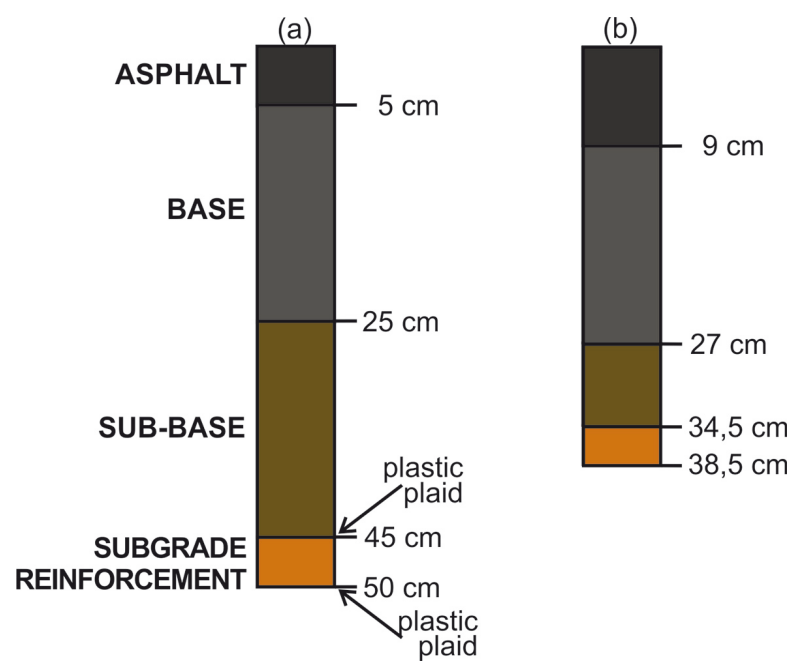

Figure 1 - Thicknesses determined by the (a) project and (b) core description.

Table 1 shows dielectric constant, resistivity and velocity for each one of these layers and also for subgrade. The dielectric constant values are based on values found in the literature for the materials considered (Daniels, 2004; Jol, 2009). The resistivity is the problematic physical parameter. The soil resistivity varies from 1 to 50,000 ohm.m, according to W.A. Sauck (personal com.). It was used 50 ohm.m - that is, 0.02 Siemens $/ \mathrm{m}$, the minimum average conductivity $\sigma$ obtained for the depth from 0 to $2 \mathrm{~m}$ from vertical electrical soundings done in Belém by Mendes (2000) using Dar Zarrouk parameters (Maillet, 1947). The velocity $v$ of each layer was calculated on the basis of the equation $v=c / \sqrt{\varepsilon_{r}}$, where $c$ is the light velocity in vacuum $(\approx 0.3 \mathrm{~m} / \mathrm{ns})$ and $\varepsilon_{r}$ is the dielectric constant (Annan, 2001).

\section{GPR METHOD}

The theory of the method is based on the propagation of electromagnetic waves, summarized in Maxwell's equations. GPR uses electromagnetic pulses with frequencies ranging from $10 \mathrm{MHz}$ to $2.5 \mathrm{MHz}$ (Saarenketo, 2006). Pulses are emitted by a transmitting antenna, penetrate the subsurface, and are reflected back to the surface, where they are recorded by a receiving antenna, which may be the same as or distinct from the transmitting antenna.

The recorded pulses are displayed as electromagnetic waves, with the wave amplitude and the time elapsed between transmission and reflection, in a diagram known as a radargram. Changes in wave amplitude are attributed to variations in the electromag- netic properties of the propagating medium. The thickness of the medium is estimated by measuring the time elapsed between the propagation and the reflection of the wave.

Variations in the electromagnetic properties are primarily influenced by the water content of the medium: an increase in water content causes an increase in the amplitude of the reflections (Topp et al., 1980).

\section{FIELD WORK}

The field data were collected with GPR equipment manufactured by Geophysical Survey System, Inc. (GSSI); a model SIR System 3000 from UFPA, and a $900 \mathrm{MHz}$ antenna from the Federal University of Ceará.

Common-offset acquisition geometry was used, in which transmitting and receiving antennas are separated by a fixed distance and moved along a line. The measurements were taken in continuous mode, in which the antenna is moved along the surface at a constant speed.

The data acquisition parameters were: spacing between the traces of $2 \mathrm{~cm}$; time window of $20 \mathrm{~ns} ; 1024$ samples per trace and temporal sampling interval of 0.01953125 ns.

A longitudinal line (LR149) $190 \mathrm{~m}$ in length in the center of a new road in CEAMAZON was investigated in order to investigate changes in pavement thickness along the same. Twenty-one additional lines, which varied between 6.5 and $7 \mathrm{~m}$ in length, were also surveyed (from west to east, TR128 to TR148). They were $20 \mathrm{~cm}$ apart from each other, crossing perpendicular to LR149. The $20 \mathrm{~cm}$ spacing was used in order to investigate changes in pavement thickness between the center and the edges of the pavement. Figure 2 shows the area where data were collected.

A borehole was drilled at coordinates $1^{\circ} 27^{\prime} 60^{\prime \prime} S$, $48^{\circ} 26^{\prime} 45^{\prime \prime} \mathrm{W}$ (Fig. 2). The borehole enabled the identification of four layers, which are shown together with the layers required by project specifications in Figure 1. It also determined the thickness of these layers, thus allowing for correlation of radargram reflectors with the interfaces of the pavement layers.

The borehole's first layer, which is approximately $9 \mathrm{~cm}$ thick, corresponds to hot mix asphalt concrete. Half of the thickness of this layer is formed by gravel sealed with asphalt mix. The second layer, the base, is $18 \mathrm{~cm}$ thick, is mostly dry, and is composed of small gravel, approximately $2 \mathrm{~cm}$ in diameter, with a small fraction of sand. The third layer, the sub-base, is $7.5 \mathrm{~cm}$ thick, is relatively moist, and consists of larger-sized gravel than the previous layer, with a large fraction of sand.

The fourth layer, subgrade reinforcement, is $4 \mathrm{~cm}$ thick and consists of gravel of various sizes, as well as fractions of sand 
Table 1 - Depth, physical parameters and layer velocities.

\begin{tabular}{|c|c|c|c|c|c|}
\hline Layer & $\begin{array}{c}\text { Depth } \\
(\mathrm{cm})\end{array}$ & $\begin{array}{c}\text { Thickness } \\
(\mathrm{cm})\end{array}$ & $\begin{array}{c}\text { Dielectric } \\
\text { constant }\end{array}$ & $\begin{array}{c}\text { Conductivity } \\
(\mathrm{S} / \mathrm{m})\end{array}$ & $\begin{array}{c}\text { Velocity } \\
(\mathrm{m} / \mathrm{s})\end{array}$ \\
\hline Asphalt & $0-5$ & 5 & 5.33 & $10^{-2}$ & 0.13 \\
\hline Base & $5-25$ & 20 & 14 & $2 \times 10^{-4}$ & 0.08 \\
\hline Sub-base & $25-45$ & 20 & 11 & $5 \times 10^{-4}$ & 0.09 \\
\hline $\begin{array}{c}\text { Subgrade } \\
\text { Reinforcement }\end{array}$ & $45-50$ & 5 & 16 & $17 \times 10^{-3}$ & 0.075 \\
\hline Subgrade & $>50$ & & 36 & $2 \times 10^{-2}$ & 0.05 \\
\hline
\end{tabular}

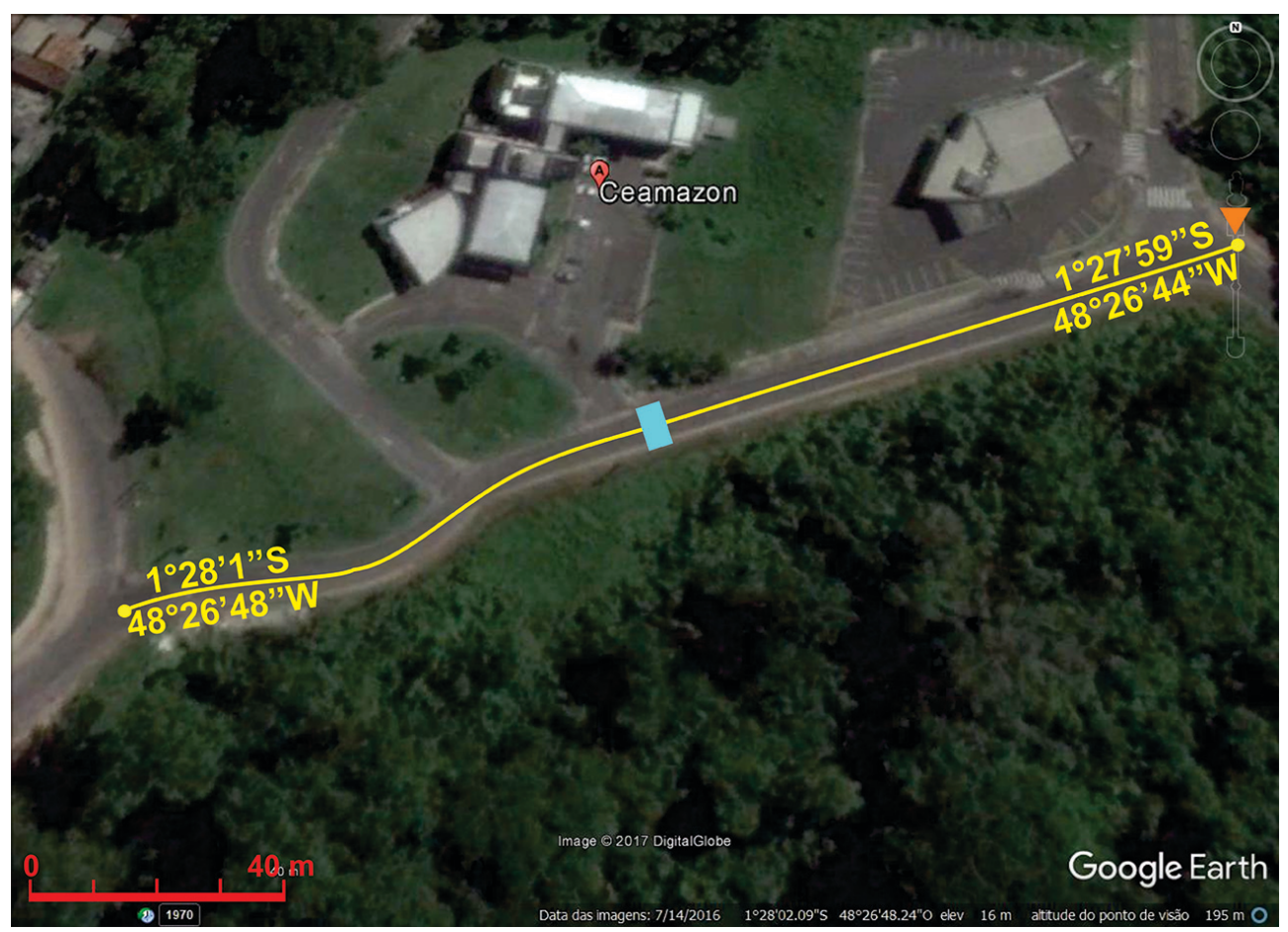

Figure 2 - Satellite image of study area (Google ${ }^{\circledR}$ Earth, 2017). Yellow line: LR149. Blue rectangle: TR128-TR148. Orange triangle:

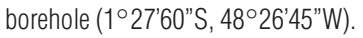

and clayey material. The clay fraction most likely originated from the landfill layer because the last pavement layer is in contact with the underlying landfill. Above the subgrade reinforcement and above the sub-base, there is a plastic mat whose purpose is to stabilize the overlying layers and to prevent the ingress of materials from underlying layers such as the landfill clay above quaternary sediments.

\section{DATA PROCESSING}

The GPR data are processed to facilitate visualization and interpretation. The processing must be adapted to the purpose of the work. Processing steps used in this study coincide with the basic processing steps described by Annan (1999), and were conducted with ReflexW (Sandmeier, 2016). Figure 3 shows the processing steps.

After converting the raw reads to the ReflexW format, the zero-offset correction was performed. The traces preceding the first arrival position are caused by direct waves, as well as instabilities during data acquisition, such as bad coupling of the antenna with the surface. This correction puts the first arrival of all the traces in the same position and eliminates the parts of the traces preceding the first arrival. Time zero was taken as the point prior to the evolution of the first cycle of the direct wave.

The gain incorporated by the equipment into the field data (to allow a first visualization) (Table 2) was removed so that 
the filtering operations could be carried out without any existing noise being enhanced by the gain.

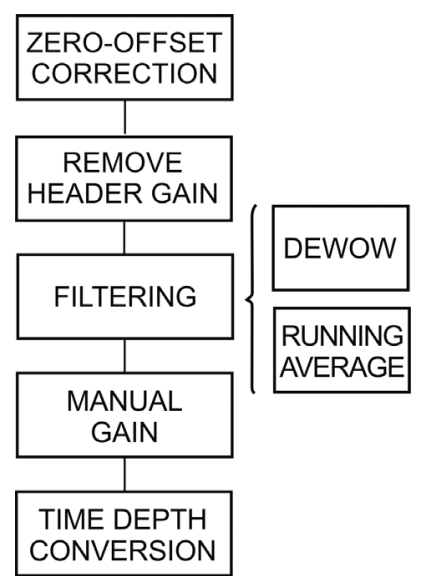

Figure 3 - Processing flowchart.

Table 2 - Gain applied by the device in the surveying and gain applied in the processing.

\begin{tabular}{|c|c|c|}
\hline \multirow{2}{*}{ Time (ns) } & \multicolumn{2}{|c|}{ Gain $(\mathrm{dB})$} \\
\cline { 2 - 3 } & Device & Processed \\
\hline 0 & 5 & -10 \\
\hline 5 & 5 & \\
\hline 10 & 32 & \\
\hline 15 & 45 & \\
\hline 20 & 45 & 20 \\
\hline
\end{tabular}

Filters are applied to remove undesirable effects, such as ambient, electronic, or operational noises from the data, and to improve the data's visual quality. Filters can be temporal (acting in each time trace) or spatial (acting in multiple traces) within a certain distance of each other, (besides 1D) or a combination of both (2D).

Dewow filtering was applied first (1D), since signal amplitude reaches saturation due to the low-frequency components (diffuse low frequencies that are not within the GPR's usable frequency range) coupled to the signal, which may cause some wow distortion in the radargram. It consists of calculating the moving average for each stroke value within the chosen time window, which is adjusted to approximately one period (1.1 ns), followed by its subtraction from the central value of the window.

The running average filter was also used (2D), which performs a running average over a selectable number of traces for each time step. It used a bandwidth of 32 as the current sample, then took into account the next 16 samples horizontally to the left and the next 16 horizontally to the right, i.e. 33 samples for each time value. From these samples the mean value was calculated and assigned to the current sample as the new value. This filter suppresses trace dependent noise and emphasizes horizontally coherent energy.

The next step was to apply manual gain on the time axis ( $y$-axis), with the characteristics shown in Table 2.

The radargram represents the GPR data record in the spacetime domain. To convert it to the space-depth domain an estimate of the propagation velocity of the electromagnetic radiation in the subsurface for each layer was used. This estimate was based on the correlation between layer thicknesses found within the borehole (Fig. 1), and the radargram data from nearest the borehole. Table 1 was built with the velocities used.

For comparison, the time-depth conversion was also performed using only a speed of $0.11 \mathrm{~m} / \mathrm{ns}$, obtained by diffraction hyperbola adjustment (Fig. 4).

\section{RESULTS}

Amplitude changes can occur at the transition between two media, due to contrasts in dielectric values: if the dielectric properties of two adjacent media are sufficiently different, the amplitude of the signal reflected from the interface will be strong (Saarenketo \& Scullion, 2000; Grote et al., 2005). Changes in the signal amplitude without lateral continuity can be associated with the ingress of material from other layers.

The amount of attenuation is a function of the electrical conductivity of the materials and the frequency of the emitted signal. The attenuation is greater in materials with higher conductivities - for example, media with high moisture content or moist clays - and at higher frequencies (Topp et al., 1980; Annan, 1999; Saarenketo \& Scullion, 2000; Grote et al., 2005). Other explanations for amplitude changes include content variations (lithological and particle size variation) and, to a lesser extent, density (compaction) (Andrade, 2005).

Figure 5 shows the raw radargram (with field gain), processed radargram, interpreted radargram, and the layers section obtained. The last also shows the drilled borehole.

Based on the most evident reflectors in the section near the borehole and on the borehole results themselves, four interfaces were delineated. The interface between the first and the second layer shows good continuity. The same does not occur at the second interface, probably due to differences in density variations (compaction) and moisture variations within the material. The zones with attenuation can be explained by local clay enrichment. Signs of local material movement seem to be indicated by the radargram.

It should be noted that the thickness of the first layer corresponds not only to the asphalt cover but also to part of the 


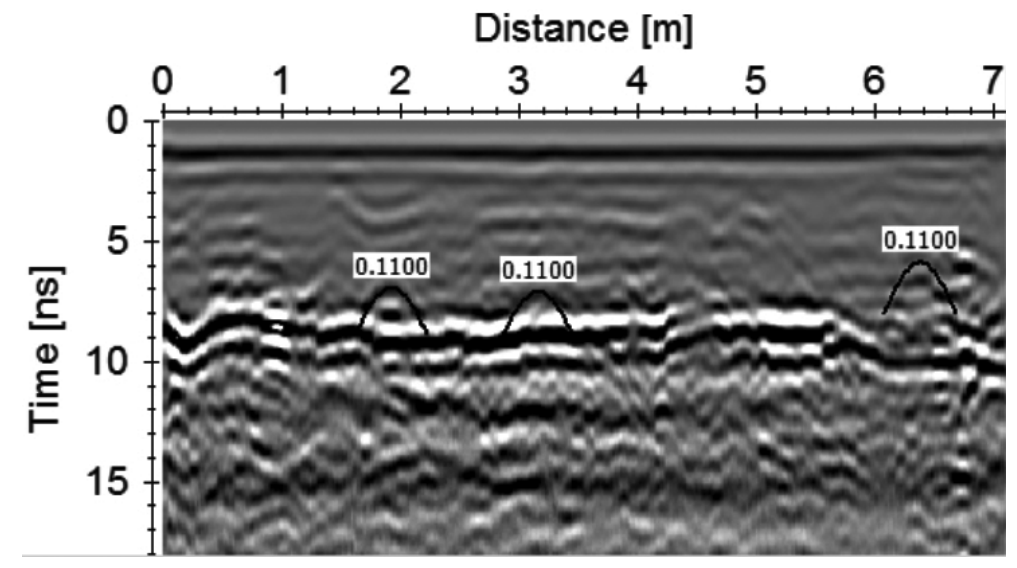

Figure 4 - Diffraction hyperboles in radargram TR147.
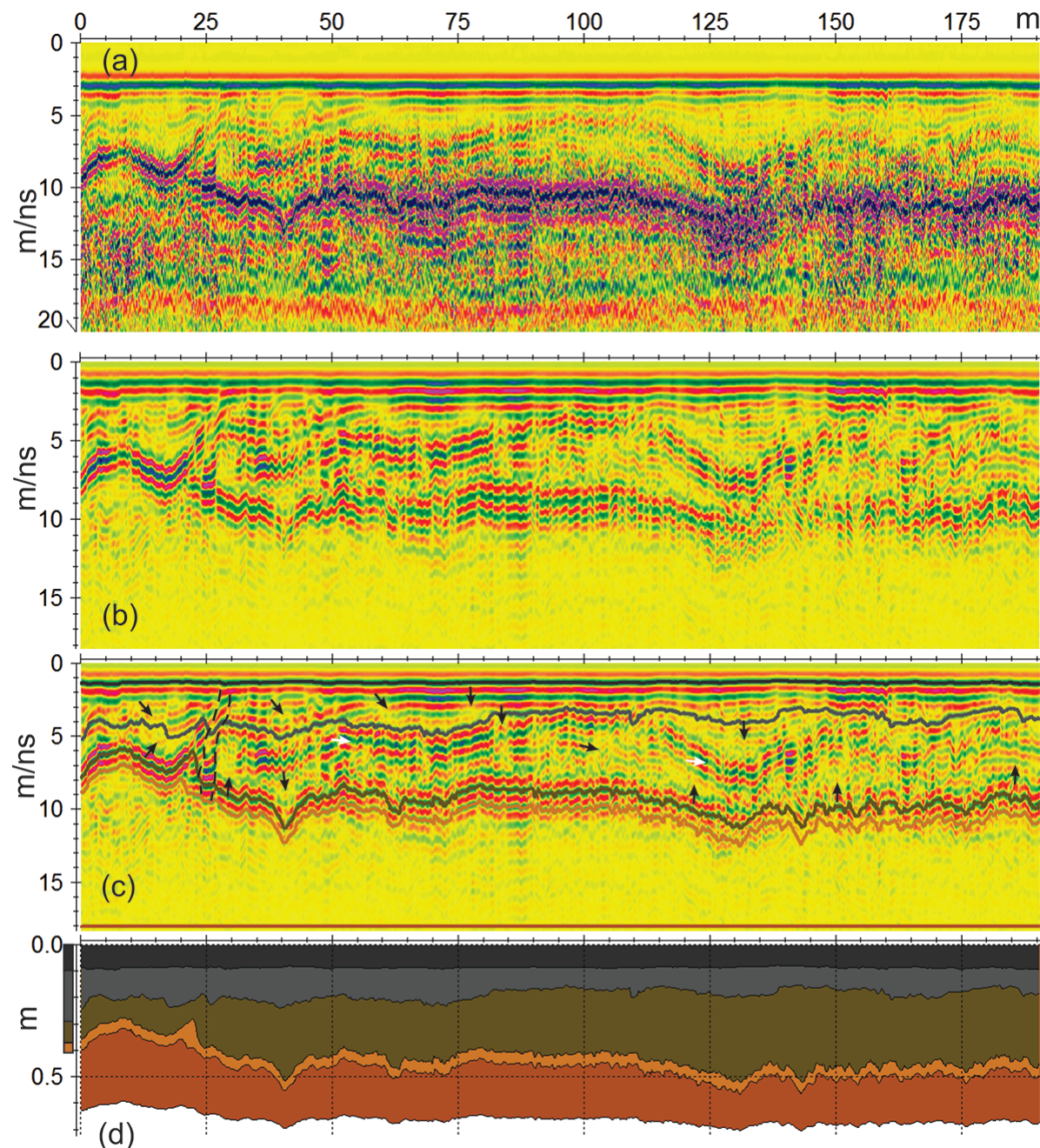

Figure 5 - LR149 - (a) Raw, (b) processed, and (d) interpreted radargrams. (e) Layers section showing the borehole position (links) Black Arrows: clay enrichment. White Arrows: differential compaction in layer. Dashed vertical line in (c): material movement. 
base, which is virtually indistinguishable from the cover, as observed in the borehole. The thickness estimation of the thin top surface is still a difficult problem due to the limitations of GPR resolution and the similar permittivity of asphalt sub-layers (Dong et al., 2016).

The subgrade reinforcement marks the boundary between the pavement and the landfill, which can be observed by the change in the pattern of reflections from high-amplitude horizontal reflections, to very low-amplitude, irregular reflections, which may show that the substrate or landfill contains more clay than the overlying layer.

Table 3 shows the thickness of each layer as required by the pavement project specifications, with their actual thickness as identified by the core and by GPR, and also the error between each layer's thickness and the thickness required by the project specifications. The results for LR149, applying different velocities for each layer, compared with using only $0.11 \mathrm{~m} / \mathrm{ns}$ per layer (from diffraction hyperbola adjustment) are shown on Table 3 , respectively. Results for one of the transversal radargrams (TR147) using different velocities for each layer are also shown in Table 3.

The errors are considerable near the borehole, and become smaller as we move away in the direction of the start of the new asphalt road. The average total thickness obtained for the pavement in LR149 is $6.4 \%$ less than that required by the original pavement project. For the transversals it is of the same order of magnitude (for TR147, for example, it is 9\%). The use of a single velocity value (obtained, for example, by hyperbolic adjustment) for the time-depth conversion leads to larger errors $(+13.2 \%$ instead of $-6.4 \%)$. In the transversals there is little difference in total thickness shown between the center and at least one of the edges: almost all of them showed somewhat lower thickness in the center.

\section{DISCUSSION AND CONCLUSIONS}

The thicknesses of the individual layers observed in the borehole and obtained by the radargrams are not in agreement with those required by the original pavement project specifications, and the total thickness of the pavement is less than that defined in the specifications.

The errors found in this pavement project are larger than the 4\% average error of GPR results reported by Hu et al. (2016), an error margin obtained when GPR results are calibrated with core thicknesses, as was done in the present CEAMAZON study.

What does draw attention, however, is the existence of attenuation zones and bedding zones of excellent contrast within the layers. The latter seem to be related to the presence of gravel, while the former, to the inappropriate presence of clay, contained in the layers.

A possible explanation for the discrepancies lies in the relative costs of the materials used. Clay, sand and gravel have the following cost ratio: 1:1.6:5.2 per cubic meter. Gravel is by

Table 3 - Layer thicknesses according to pavement project, core, and radar, and errors between them. LR149 and LR149(0.11) - Longitudinal radargram converted to the space domain with different velocities for each layer, and with $0.11 \mathrm{~m} / \mathrm{ns}$, respectively. TR147 - Transversal radargram 147 (layers with different velocities). Av - Average; Std Dev - Standard Deviation.

\begin{tabular}{|c|c|c|c|c|c|}
\hline \multicolumn{3}{|c|}{ Thicknesses (cm) } & \multirow{2}{*}{$\begin{array}{c}\text { LR149 } \\
\text { Av } \pm \text { Std Dev }\end{array}$} & \multirow{2}{*}{$\begin{array}{l}\text { LR149(0.11) } \\
\text { Av } \pm \text { Std Dev }\end{array}$} & \multirow{2}{*}{$\begin{array}{c}\text { TR147 } \\
\text { Av } \pm \text { Std Dev }\end{array}$} \\
\hline Layer & Project & Core & & & \\
\hline Asphalt & $\overline{5}$ & $\overline{9}$ & $8.7 \pm 0.003$ & $8.7 \pm 0.003$ & $9.1 \pm 0.002$ \\
\hline Base & 20 & 18 & $10.3 \pm 0.021$ & $12.9 \pm 0.029$ & $9.3 \pm 0.16$ \\
\hline Sub-base & 20 & 7.5 & $23.5 \pm 0.061$ & $28.7 \pm 0.075$ & $22.5 \pm 0.026$ \\
\hline $\begin{array}{c}\text { Subgrade } \\
\text { Reinforcement }\end{array}$ & 5 & 4 & $4.3 \pm 0.008$ & $6.3 \pm 0.012$ & $4.6 \pm 0.007$ \\
\hline Total thickness & 50 & 38.5 & 46.8 & 56.6 & 45.5 \\
\hline \multicolumn{6}{|c|}{ Error (\%) } \\
\hline \multicolumn{2}{|l|}{ Layer } & $\begin{array}{l}\text { Core- } \\
\text { Project }\end{array}$ & $\begin{array}{l}\text { LR149a- } \\
\text { Project }\end{array}$ & $\begin{array}{c}\text { LR149b- } \\
\text { Project }\end{array}$ & $\begin{array}{l}\text { TR147- } \\
\text { Project }\end{array}$ \\
\hline \multicolumn{2}{|l|}{ Asphalt } & 80.0 & 74.0 & 74.0 & 82.0 \\
\hline \multicolumn{2}{|l|}{ Base } & -10.0 & -48.5 & -35.5 & -53.5 \\
\hline \multicolumn{2}{|c|}{ Sub-base } & -65.0 & 17.5 & -43.5 & 12.5 \\
\hline \multicolumn{2}{|c|}{ Subgrade Reinforcement } & -20.0 & -14.0 & 26.0 & -8.0 \\
\hline \multicolumn{2}{|l|}{ Total } & -24.0 & -6.4 & 13.2 & -9.0 \\
\hline
\end{tabular}


far the most expensive paving component in the Amazon region. The gravel that is used in the base and sub-base layers is more expensive per cubic meter than a square meter of asphalt $5 \mathrm{~cm}$ thick, at a ratio of 1:3.3. This occurs because rocks in Amazônia are rare in comparison with sediments from the tropical overburden, due to the climate.

On the other hand, the use of a single velocity value for the time-depth conversion leads to larger errors. In the case studied, it indicated a thickness greater than that defined in the specifications.

Thus, this experiment showed that GPR can be an excellent tool to verify if road construction is being performed in accordance with contract specifications. The GPR checks must be done in the center of the road, because the thickness can be somewhat lower than in the edges as indicated by the transversal radargrams. Where there are areas of dubious quality, such as those reported, we consider it fundamental to perform other boreholes to verify them; the acquired knowledge could then be used for GPR study for longer stretches of pavements.

\section{ACKNOWLEDGEMENTS}

Thanks to the National Council for Scientific and Technological Development (Conselho Nacional de Desenvolvimento Científico e Tecnológico - CNPq), for the incentive provided through scholarship for the lead author's dissertation, to the graduate program in Geophysics (CPGf/UFPA) for supporting the field work, to the Universidade Federal do Pará (UFPA), Campus Guamá, for allowing the field work to be performed, to undergraduate and graduate colleagues for logistical support, to Professor Raimundo Mariano Castelo Branco from the Universidade Federal do Ceará (UFC) who provided the antenna, and especially to Professor Welitom Borges (UnB) for helping us with the field work, and for his suggestions. Thanks also for the valuable suggestions from the referees.

\section{REFERENCES}

AGUIAR JCM. 2005. Radar de penetração no solo (GPR) - aspectos geofísicos e geodésicos, processamento e análise em pavimento flexível. Master Dissertation (Ciências Geodésicas e Tecnologias da Geoinformação) - Programa de Pós-graduação em Ciências Geodésicas e Tecnologias da Geoinformação, Departamento de Engenharia Cartográfica, Universidade Federal de Pernambuco, Brazil, 2005. 128 pp.

ALVES TSF. 2007. Metodologias de auscultação de pavimentos rodoviários - aplicação prática do radar de prospecção e do deflectômetro de impacto. Master Dissertation (Engenharia Civil) - Instituto Superior Técnico, Universidade Técnica de Lisboa, 2007. 136 pp.
ANDRADE PRO. 2005. Interpretação de dados de GPR com base na hierarquização de superfícies limitantes e na adaptação de critérios sismoestratigráficos. Master Dissertation (Geofísica), Programa de Pósgraduação em Geodinâmica e Geofísica, Centro de Ciências Exatas e da Terra, Universidade Federal do Rio Grande do Norte, Brazil, 2005. 67 pp.

ANGIÓ CG, MANACORDA G, PINELLI A \& BENEDETTO. 2003. GPR automatic inspection of road pavement layer thickness. In: International Symposium on Rehab and Maintenance of Roads MAIREPAV, 13. Proceedings... Portugal, 2003, 641-651.

ANNAN AP. 1999. Practical processing of GPR data. Mississauaga, Sensors \& Software, Inc., Internal Report. 18 pp.

ANNAN AP. 2001. Ground penetration radar workshop notes. Sensors \& Software, Inc., Internal Report, $197 \mathrm{pp}$.

BERNUCCI LB, MOTTA LMG, CERATTI JAP \& SOARES JBS. 2006. Pavimentação asfáltica: formação básica para engenheiros. PETROBRAS: ABEDA, Rio de Janeiro, Brazil, 504 pp.

BORGESWR, SILVA LA, CUNHA LS, CASTELOBRANCO RMG \& FARIAS MM. 2014. GPR Applied to Rigid Pavement from Santos Dumont Airport, RJ. Brazilian Journal of Geophysics, 32(2): 225-234.

DANIELS DJ. 2004. Ground Penetrating Radar. The Institution of Electrical Engineers. 2nd ed., London, 734 pp.

DONG Z, YE S, GAO Y, FANG G, ZHANG X, XUE Z \& ZHANG T. 2016. Rapid Detection Methods for Asphalt Pavement Thicknesses and Defects by a Vehicle-Mounted Ground Penetrating Radar (GPR) System. Sensors, 16(12): 2067.

GOMES AFSS. 2008. Tecnologia aplicada à avaliação das estruturas dos pavimentos aeroportuários. Monografia (Especialização em Gestão da Aviação Civil), Centro de Formação de Recursos Humanos em Transportes, Universidade de Brasília, Brazil, 2008, 75 pp.

GROTE K, HUBBARD S, HARVEY J \& RUBIN Y. 2005. Evaluation of infiltration in layered pavements using surface GPR reflection techniques. Journal of Applied Geophysics, 57(2): 129-153.

HICKMAN S, CARDIMONA S, WEBB D, LIPPINCOTT T, WENZLICK J \& ANDERSON N. 2000. Ground penetrating radar survey of Interstate 70 across Missouri. In: International Conference on the Application of Geophysical Technologies to Planning, Design, Construction and Maintenance of Transportation Facilities and Infrastructure, 1., 2000. St. Louis, 4-22. $9 \mathrm{pp}$.

HU J, VENNAPUSA PKR, WHITE DJ \& BERESNEV I. 2016. Pavement thickness and stabilized foundation layer assessment using groundcoupled GPR. Nondestructive Testing and Evaluation, 3: 1-21.

HUGENSCHMIDT J, PARTI MN \& WITTE H. 1998. GPR inspection of a Mountain Motorway in Switzerland. Journal of Applied Geophysics, 40(3): 95-104.

JOL HM. 2009. Ground penetrating radar: theory and applications. United Kingdom, UK, Elsevier Science. 524 pp. 
LAHOUAR S \& AL-QADI L. 2008. Automatic detection of multiple pavement layers from GPR data. NDT\&E International, 41(2): 69-81.

LENNGRENCA, BERGSTROM J \& ERSSONB. 2000. Using ground penetrating radar for assessing highway pavement thickness. In: Subsurface Sensing Technologies and Applications. Society of Photo-Optical Instrumentation Engineers, 4129. Proceedings... San Diego, 474-483.

LIMA FILHO FP, MENEZES L, FREIRE RC, PORSANI JL \& MORAES JB. 2004. Aplicação do método GPR na identificação de causas de deformação no pátio de estacionamento do Aeroporto Internacional Pinto Martins em Fortaleza/CE. Revista de Geologia, 17(2): 143-156.

LOPES OA. 2009. Uso do GPR (Ground Penetrating Radar) em trechos de pavimentos da cidade universitária da UFRJ. Master Dissertation (Engenharia Civil), Programa de Pós-Graduação em Engenharia Civil, Instituto Alberto Luiz Coimbra de Pós-Graduação e Pesquisa de Engenharia (COPPE), Universidade Federal do Rio de Janeiro, Brazil, 2009. $185 \mathrm{pp}$.

MAILLET R. 1947. The fundamental equations of electrical prospecting. Geophysics, 22: 529-556.

MASER KR. 2002. Use of ground penetrating radar data for rehabilitation of composite pavements on high-volume roads. Transportation
Research Record, 1808: 122-126.

MENDES RLR. 2000. Geofísica Aplicada ao Mapeamento de Aquíferos da Região Metropolitana de Belém. Master Dissertation (Geofísica), Curso de Pós-graduação em Geofísica, Centro de Geociências, Universidade Federal do Pará, Brazil, 2000, 86 pp.

MOREY RM. 1998. Ground penetrating radar for evaluating subsurface conditions for transportation facilities. National Cooperative Highway Research Program Synthesis, 255. 46 pp.

SAARENKETO T. 2006. Electrical properties of road materials and subgrade soils and the use of ground penetrating radar in traffic infrastructure surveys. Oulu: Ph.D. Thesis, University of Oulu, 2006. 121 pp.

SAARENKETO T \& SCULLION T. 2000. Road evaluation with ground penetrating radar. Journal of Applied Geophysics, 43: 119-138.

SANDMEIER KJ. 2016. ReflexW Version 8.1. Program for the processing of seismic, acoustic or electromagnetic reflection, refraction and transmission data. Software Manual. Karlsruhe, Germany, 652 pp.

TOPP GC, DAVIS JL \& ANNAN AP. 1980. Electromagnetic determination of soil water content: measurements in coaxial transmission Radargrams. Water Resources Research, 16(3): 574-582. 